\title{
ANALISIS PENGARUH PERCEIVED VALUE, PERCEIVED EASE OF USE DAN PERCEIVED USEFULNESS TERHADAP NIAT BELI KEMBALI SECARA ONLNE DI KOTA YOGYAKARTA
}

\author{
Muthiara Nurul Ikhsani \\ ikhsani.muthiara@yahoo.com
}

\begin{abstract}
ABSTRAK
Tujuan dari penelitian ini adalah : (1) Untuk mengetahui pengaruh perceived value terhadap niat beli kembali online di kota Yogyakarta. (2) Untuk mengetahui pengaruh perceived ease of use terhadap niat beli kembali online di kota Yogyakarta. (3) Untuk mengetahui pengaruh perceived usefulness terhadap niat beli kembali online di kota Yogyakarta.

Variabel dalam penelitian ini adalah Perceived Value, Perceived Ease of Use dan Perceived Usefulness. Populasi dalam penelitian ini adalah konsumen atau masyarakat yang pernah melakukan pembelian secara online di kota Yogyakarta. Teknik pengambilan sampel yang digunakan adalah accidental sampling yaitu metode pemilihan sampel yang diambil dari anggota populasi yang dipilih secara kebetulan sesuai tujuan tertentu. Teknik pengumpulan data menggunakan kuesioner. Analisis yang digunakan adalah analisa regresi berganda.

Dari hasil penelitian disimpulkan bahwa : Hasil pengujian hipotesis 1 menunjukan bahwa X1 (Perceived Value) berpengaruh secara positif terhadap Y (Niat Beli Kembali), semakin banyak orang yang menyadari tentang Perceived Value maka semakin meningkat pula niat beli kembali konsumen untuk melakukan pembelian tersebut. Hasil pengujian hipotesis 2 menunjukan bahwa X2 (Perceived Ease of Use) berpengaruh secara positif terhadap Y (Niat Beli Kembali) semakin menyadari Perceived Ease of Use maka semakin meningkat pula niat konsumen untuk memilih kembali pembelian tersebut. Hasil pengujian hipotesis 3 menunjukan bahwa X3 (Perceived Usefulness) berpengaruh secara positif terhadap Y (Niat Beli Kembali) semakin banyak orang yang memperhatikan faktor Perceived Usefulness maka semakin meningkat pula niat konsumen untuk menggunakan pembelian tersebut.
\end{abstract}

Kata kunci : Perceived Value, Perceived Ease of Use, Perceived Usefulness.

\section{PENDAHULUAN}

1.1 Latar Belakang

Kemanjuan teknologi informasi saat ini menempatkan sistem informasi sebagai elemen penting dalam aktivitas sehari-hari. Salah satu tren dalam teknologi informasi adalah pemanfaatan internet. Internet sebagai jaringan komputer global mempunyai fungsi yang penting yaitu sebagai media telekomunikasi dan media perdagangan elektronik. Terlebih dengan semakin banyak baik sekolah atau instansi pendidikan lain yang mewajibkan murid-muridnya untuk mengenal internet, dan juga banyaknya situs jejaring sosial yang membuat masyarakat yang menjadikan internet sebagai suatu kebutuhan. Hal itu dibuktikan dengan semakin banyaknya rumah, sekolah ataupun kantor yang sudah memiliki jaringan internet dan juga semakin banyaknya tempat-tempat menjadi hotspot area. Berkembangnya internet membuat banyak hal baru pula yang timbul. Salah satunya adalah pembelian atau belanja barang maupun jasa secara online, berbelanja barang secara online kini telah menjadi alternatif cara pembelian suatu barang ataupun jasa. Penjualan secara online pun juga terus berkembang baik dari segi pelayanan, efektivitas, keamanan dan juga secara popularitas (Laohapengsang, 2009).

Cara tradisional (face to face) yang dilakukan konsumen ketika membeli sebuah barang atau jasa dengan 
langsung datang ke toko yang menjual barang yang diinginkan, sehingga konsumen dapat melihat dan mencoba barang yang mereka inginkan, hal tersebut dapat membantu konsumen dalam mengambil keputusan pembelian. Akan tetapi kadang barang yang diingikan tidak dijual di toko-toko terdekat. Hal inilah yang membuat konsumen kemudian melakukan pembelian online ,melalui pembelian secara online konsumen dapat membeli barang yang mereka inginkan tanpa harus datang langsung ke tempat penjual tetapi hanya cukup memilih barang yang mereka inginkan melalui internet, hal tersebut memungkinkan konsumen untuk membeli suatu barang yang dijual di berbagai tempat manapun, karena aktivitas mulai dari memilih memesan, ataupun membeli dilakukan secara online. Pembelian online dapat dilakukan melalui situs-situs jejaring seperti facebook, website online, blog, toko bagus, berniaga.com dan situs-situs lain baik barang maupun jasa sudah merambak dalam internet. Inilah yang menyebabkan pembelian secara online semakin banyak yang menggunakan.

Faktor perceived value, dengan faktor ini konsumen membandingkan kegunaan dari pembelian secara tradisional dan pembeliaan secara online yang di mana pembelian secara online dirasa merasakan nilai-nilai yang nyata dari segi waktu, kualitas dll.

Davis et al. (1989) mendifinisikan faktor kemudahan sebagai tingkat dimana seseorang meyakini bahwa penggunaan sistem informasi adalah mudah dan tidak memerlukan usaha keras pemakainya untuk dapat melakukannya. Berdasarkan definisinya maka dapat diketahui bahwa konstruk perceived ease of use ini juga merupakan suatu kepercayaan tentang proses pengambilan keputusan atau niat membeli. Jika seseorang percaya bahwa sistem informasi tersebut mudah untuk digunakan maka orang tersebut akan menggunakannya.

Davis (1989) mendifinisikan

perceived usefulness sebagai "suatu tingkatan dimana seseorang percaya bahwa menggunakan sistem tersebut dapat meningkatkan kinerjanya dalam bekerja". Dengan demikian maka dapat diambil kesimpulan bahwa persepsi kegunaan suatu kepercayaan tentang proses pengambilan keputusan. Penelitian Davis(1989) menunjukkan bahwa konstruk percelved usefulness mempengaruhi secara positif dan signifikan terhadap penggunaan sistem informasi. Semua faktor tersebut dapat berpengaruh terhadap niat beli kembali konsumen secara online.

1.2 Rumusan Masalah

1.2.1 Apakah perceived value berpengaruh terhadap niat beli kembali secara online di kota Yogyakarta?

1.2.2 Apakah perceived ease of use berpengaruh terhadap niat beli kembali secara online di kota Yogyakarta?

1.2.3 Apakah perceived usefulness berpengaruh terhadap niat beli kembali secara online di kota Yogyakarta?

1.3 Tujuan Masalah

Berdasarkan perumusan masalah diatas, maka tujuan dari penelitian ini adalah untuk mengetahui :

1.3.1 Untuk mengetahui pengaruh perceived value terhadap niat beli kembali secara online di kota Yogyakarta.

1.3.2 Untuk mengetahui pengaruh perceived ease of use terhadap niat beli kembali secara online di kota Yogyakarta.

1.3.3 Untuk mengetahui pengaruh perceived usefulness terhadap niat beli kembali secara online di kota Yogyakarta.

\section{LANDASAN TEORI}

2.1 Tinjauan Pustaka

2.1.1 Niat Beli

Niat beli adalah tahap 
kecenderungan responden untuk bertindak sebelum benar-benar melakukan pembelian (Kinnear, 1995).engertian niat beli menurut Basu Swastha (1993:251) yaitu mengidentifikasikan semua pilihan yang mungkin untuk memecahkan persoalan itu dan menilai pilihan-pilihan secara sistematis dan obyektif serta sasaran-sasarannya yang menetukan keuntungan serta kerugiannya masing-masing.

Sedangkan menurut Philip Kotler (1998) bahwa perilaku konsumen menentukkan niat beli konsumen. Pemasar perlu memusatkan perhatian pada niat beli konsumen. Proses pembelian oleh konsumen merupakan sebuah pendekatan penyesuian masalah yang terdiri dari 5 tahap yang dilalui konsumen, kelima tahap tersebut adalah : pengenalan kebutuhan, pencarian informasi, evaluasi berbagai alternatif, keputusan pembelian dan perilaku pasca pembelian.

Menurut Tjiptono

mendefinisikan online repurchase intention sebagai keinginan pelanggan untuk melakukan pembelian ulang untuk waktu yang akan datang.

\subsubsection{Perceived Value}

$$
\text { Zeithaml (1988, }
$$

mengkonseptualisasikan value sebagai tradeoff antara komponen "give" ( harga ) dengan komponen "get" ( kualitas ). Hal ini menunjukkan :

a. Value is price first and quality second.

b. Value adalah harga terendah bagi suatu brand yang berkualitas.

c. Value sama dengan kualitas.

$d$. Value is what the consumer gets for what they give

Zeithaml ( 1998 ) dalam penelitiannya mengemukakan bahwa penilaian keseluruhan konsumen terhadap manfaat dari segi suatu produk yang didasarkan pada persepsi yang berkaitan dengan apa yang akan mereka terima dan apa yang mereka berikan. Hal ini yang menyebabkan niai yang dirasa oleh konsumen yang berpengaruh dan yang menjadi pertimbangan konsumen ketika ingin membeli produk mana yang akan dibeli.

Seperti halnya dalam menentukan pembelian secara online, transaksi secara online adalah memanfaatkan sistem layanan informasi yang lebih baik, yang bisa dilakukan dimana saja dan kapan saja. Menunjukkan harga yang transparan yang menjadikan konsumen tidak engan untuk menggunakan jual beli secara online ini.

\subsubsection{Perceived Ease of Use}

Perceived ease use didefinisikan Davis et al (1989) Chin dan Todd (1955) adalah seberapa besar teknologi komputer dirasakan relatif mudah dipahami dan digunakan.

Davis ( 1989 ) kemudahan penggunaan sebagai tingkat dimana seseorang meyakini bahwa penggunaan teknologi informasi merupakan hal yang mudah dan tidak memerlukan usaha keras untuk pemakainya. Seperti halnya pemilihan penggunaan pembelian secara online, penggunaan secara online ini merupakan transaksi yang sangat mudah untuk dilakukan oleh siapa saja, sistem yang lebih digunakan dan memudahkan memnemukan produk menunjukkan bahwa sistem tersebut lebih dikenal, lebih mudah dioperasikan sehingga sekarang ini paling banyak di gemari oleh masyarakat, hal tersebut sangat baik untuk menarik minat bagi para konsumen untuk membeli secara online di kota Yogyakarta.

\subsubsection{Perceived Usefulness}

Perceived usefulness adalah suatu tingkatan dimana seorang percaya bahwa suatu penggunaan teknologi tertentu akan meningkatkan prestasi kerja orang tersebut (Davis 1989:320). Adamson dan Shine (2003) mendefinisikan perceived usefulness 
sebagai konstruk kepercayaan seseorang bahwa penggunaan sebuah teknologi tertentu akan mampu meningkatkan kinerja mereka. Dari dua definisi tersebut dapat disimpulkan bahwa persepsi kebermanfaatan sistem berkaitan dengan produktifitas dan efektifitas sistem dari kegunaan dalam tugas secara menyeluruh untuk meningkatkan kinerja orang yang menggunakan sistem tersebut. Venkatesh dan Morris (2003) menyatakan bahwa pengaruh penting manfaat dalam pemahaman respon individual dalam teknologi informasi.

Wen et al (2011) mendefinisikan perceived usefulness sebagai penilaian konsumen terhadap manfaat informasi produk yang dibutuhkan dan dirasakan pada saat berbelanja di toko berbasis web. Hal ini yang menyebabkan kegunaan atau kebermanfaatan oleh konsumen berpengaruh dan menjadi pertimbangan konsumen ketika ingin membeli produk kembali secara online.

\subsection{Hipotesis}

2.2.1 $\mathrm{H}_{1}=$ Perceived Value berpengaruh secara positif terhadap Niat Beli Kembali.
2.2.2 $\mathrm{H}_{2}=$ Perceived Ease of Use berpengaruh secara positif terhadap Niat Beli Kembali.

\subsection{3 $\mathrm{H}_{3}=$ Perceived Usefulness berpengaruh secara positif terhadap Niat Beli Kembali.}

\section{METODOLOGI PENELITIAN}

\subsection{Sifat}

Penelitian ini adalah penelitian yang bersifat kuantitatif. Metode kuantitatif adalah pendekatan ilmiah terhadap pengambilan keputusan manajerial dan ekonomi. Penelitian kuantitatif adalah penelitian ilmiah yang sistematis terhadap bagian-bagian dan fenomena serta hubungan-hubungannya. Tujuan penelitian kuantitatif adalah mengembangkan dan menggunakan model-model matematis, teori-teori dan hipotesis yang berkaitan dengan fenomena alam. Penelitian ini bermaksud menggambarkan sesuatu keadaan obyek tertentu yang memiliki hubungan atau dipengaruhi oleh faktor lain dan penarikan kesimpulannya didasarkan pada angka yang diolah secara statistik. Penelitian ini dilakukan terhadap konsumen yang melakukan pembelian secara onlne di kota Yogyakarta.

3.2 Metode pengumpulan data

Metode yang di gunakan dalam penelitian ini adalah Kuesioner (angket). Metode ini merupakan teknik pengumpulan data yang dilakukan dengan cara memberikan seperangkat pertanyaan atau pernyataan tertulis kepada responden untuk dijawabnya, dimana peneliti tidak langsung bertanya jawab dengan responden ( Sugiono, 2013 : 142 ).

\subsection{Sampel}

Dalam penelitian ini menggunakan teknik Probability Sampling atau random sampling merupakan teknik sampling yang dilakukan dengan memberikan peluang atau kesempatan kepada seluruh anggota populasi untuk menjadi sampel. Pengambilan sampel dilakukan dengan menggunakan salah satu teknik yaitu accidental sampling adalah metode pemilihan sampel yang diambil dari anggota populasi yang dipilih secara kebetulan sesuai tujuan tertentu, yakni responden yang berjumlah 100 orang yang pernah melakukan pembelian secara online di kota Yogyakarta.

\subsection{Definisi Operasional}

\subsubsection{Perceived Value}

Perceived value adalah penilaian keseluruhan konsumen terhadap manfaat dari suatu produk yang didasarkan pada persepsi yang berkaitan dengan apa yang akan mereka terima dan apa yang mereka berikan, yang dapat diketahui dengan 
kuisioner, dan mengukur jawaban dengan skala ordinal.

\subsubsection{Perceived Ease of Use}

Perceived Ease of Use adalah berbagai kemudahan yang dirasakan konsumen sehubungan dengan penggunaan internet untuk berbagai tujuan yang ingin dicapai. Perceived Ease of Use merupakan variabel yang sangat penting untuk menerima sistem informasi karena dasar dari penggunaan sistem.

\subsubsection{Perceived Usefulness}

Perceived Usefulness adalah suatu tingkatan dimana seorang percaya bahwa suatu penggunaan teknologi tertentu akan meningkatkan prestasi kerja orang tersebut. Ukuran yang menjadi pertimbangan konsumen untuk menggunakan pembelian secara online adalah meningkatkan gaya hidup dan kenyamanan.

3.5 Analisis data

\subsubsection{Uji Validitas}

Merupakan

proses pengukuran untuk menguji kecermatan butir-butir dalam daftar pertanyaan untuk melakukan fungsi ukurannya dimana pengujian dilakukan dengan mengkorelasikan skor pada masing-masing item dan skor totalnya. Dengan rumus Pearson Product Moment ( Riduwan, 2004 ).

\subsubsection{Uji Relibilitas}

Reliabilitas merupakan proses pengukuran pada derajat ketepatan, ketelitian, dan akurasi yang ditunjukkan oleh instrument penelitian. Penelitian ini menggunakan metode Alpha untuk melakukan estimasi reliabilitas. Teknik untuk mengetahui reliabilitas seluruh tes dengan menggunakan rumus sebagai berikut ( Riduwan, 2004 ).

\subsubsection{Metode Regresi Linier} Berganda

Alat yang digunakan adalah uji regresi Linier berganda, yaitu analisis tentang variable tergantung $(\mathrm{Y})$ Dependent variable adalah niat beli kembali, dengan variable bebas (X) Independent variable adalah perceived value, perceived ease of use dan perceived usefulness.

Regresi berganda digunakan untuk mengetahui pengaruh variabel bebas terhadap variabel terikatnya secara bersama-sama. Dalam penelitian ini persamaan regresi berganda adalah ( Soehardi Sigit, $2003: 169$ ).

3.5.4 Uji Hipotesis

3.5.4.1 Uji F

Menurut

Sugiyono ( 2005 : 266 ) uji $\mathrm{F}$ digunakan untuk mengetahui pengaruh secara bersama-sama variabel independen terhadap variabel dependen. Untuk mengetahui tingkat signifikansi dari pengaruh variable independent secara keseluruhan terhadap variable dependen.

1) Jika $F$ hitung $>F$ table atau nilai signifikan ( sig ) kurang dari $5 \%$ maka $\mathrm{H}_{0}$ ditolak yang berarti signifikan atau 
variable

independen

secara

keseluruhan

berpengaruh

terhadap variable

dependen.

2) Jika $F$ hitung $<F$

table atau

signifikan ( sig )

lebih dari 5\%

maka $\mathrm{H}_{0}$ diterima

yang berarti tidak

signifikan atau

variable

independen

secara

keseluruhan tidak

berpengaruh

terhadap variable

dependen.

\subsubsection{Uji t}

Yaitu mengetahui tingkat signifikansi dari pengaruh variable independen secara individu terhadap variable dependen dengan menentukan hipotesis nol dan hipotesis alternative.

1) Jika t hitung $>t$ tabel atau nilai signifikansinya ( sig ) lebih dari $5 \%$ maka $\mathrm{H}_{0}$ diterima berarti signifikan atau variable independen yang diuji secara nyata berpengaruh terhadap variable dependen.

2) Jika t hitung $<$ t tabel atau nilai signifikannya ( sig ) lebih dari $5 \%$ maka $\mathrm{H}_{0}$ diterima yang berarti tedak sigmifikan atau variable independent yang diuji secara nyata tidak berpengaruh terhadap variable dependen.

\section{HASIL DAN PEMBAHASAN}

4.1 Uji Validitas

Uji dilakukan bertujuan untuk menguji tingkat ketepatan dalam mengukur variable perceived value, perceived ease of use dan perceived usefulness terhadap niat beli kembali. Untuk mengetahui apakah butir tersebut valid bisa dilakukan dengan membandingkan nilai probabilitas signifikansi dengan nilai alpha yang ditetapkan dengan ketentuan jika korelasi item dengan total item berkorelasi positif dan mempunyai nilai signifikansi kurang dan nilai alpha yang ditetapkan dalam hal ini 0,05 (5\%) maka butir tersebut dinyatakan valid.

Berdasarkan table di atas dapat diketahui bahwa 5 butir item pada variable Perveived value, perceived ease of use dan perceived usefulness semuanya valid. Hal ini dapat kita lihat pada kolom korelasi item dan total item berkorelasi positif dengan signifikansi 0,000 dan ada tanda bintang $(*)$.

4.2 Uji Reliabilitas

Hasil uji reliabilitas X1 ( Perceived Value ) menunjukan nilai cronbach's alpha sebesar 0,664. Nilai 0,664 adalah nilai yang baik karena keandalan kisaran 0,70 adalah bisa diterima. Hasil uji reliabilitas X2 ( Perceived ease of Use ) menunjukan nilai cronbach's alpha sebesar 0,697. Nilai 0,697 adalah nilai yang baik karena keandalan kisaran 0,70 bisa diterima. Hasil uji reliabilitas X3 ( Perceived Usefulness ) menunjukan nilai cronbach's alpha sebesar 0,723 . Nilai 0,723 adalah nilai yang baik karena keandalan lebih dari 
0,70 adalah baik. Hasil uji reliabilitas $\mathrm{Y}$ ( Niat Beli Kembali ) menunjukan nilai cronbach's alpha sebesar 0,735. Nilai 0,735 adalah nilai yang baik karena keandalan lebih dari 0,70 adalah baik.

4.3 Regresi linier berganda

Dengan koefisien sebesar 0,253 dengan tingkat signifikansi $0,008<0,05$ yang artinya variable Perceived Value berpengaruh terhadap niat beli kembali. Dengan koefisien sebesar 0,275 dengan tingkat signifikansi $0,005<0,05$ nilai ini yang paling tertinggi di antara variable lain yang artinya variable Perceived Ease of Use sangat berpengaruh terhadap niat beli kembali. Dengan koefisien sebesar 0,205 dengan tingkat signifikansi $0,044<0,05$ yang artinya variable Perceived Usefulness berpengaruh terhadap niat beli kembali.

4.4 Uji Hipotesis

\subsubsection{Uji F}

Nilai f sebesar 14,355 dengan sifnifikansi 0.000 . nilai signifikansi tersebut $<0,05$ sehingga dapat dikatakan bahwa secara serentak variable bebas berpengaruh terhadap variable terikat.

\subsubsection{Uji t}

- Nilai signifikansi variable $\mathrm{X} 1$ sebesar 0,008 yang berarti bahwa model signifikan karena signifikansi $<0,05$.

- Nilai signifikansi variable $\mathrm{X} 2$ sebesar 0,005 yang berarti bahwa model signifikan karena signifikansi $<0,05$.

- Nilai signifikansi variable X3 sebesar 0,044 yang berarti bahwa model signifikan karena signifikansi $<0,05$.

\subsection{Pembahasan}

Hasil dari regresi berganda dalam penelitian ini menunjukan bahwa variable bebas yang digunakan dalam penelitian ini hanya mempengaruhi variable terikat sebesar 0,288 Hal ini menunjukan bahwa 71,2\% factor lain yang dapat mempengaruhi niat beli kembali online di kota Yogyakarta.

Dari hasil regresi berganda dalam bentuk persamaan yaitu $\mathrm{Y}=0,253 \mathrm{X} 1+$ $0,275 \mathrm{X} 2+0,205 \mathrm{X} 3$ dapat dilihat diantara 3 variable Perceived Value, Perceived Ease of Use dan Perceived Usefulness yang paling dominan atau yang paling berpengaruh terhadap Niat Beli Kembali adalah variable X2 ( Perceived Ease of Use ) dengan nilai sebesar 0,275 artinya penggunaan transaksi online sangat memperhatikan Perceived Ease of Use seperti : kejelasan tujuan teknologi informasi dan kemudahan penggunaan sistem untuk tujuan sesuai dengan keinginan pemakai, maka akan semakin tinggi pula niat para konsumen terhadap pembelian secara online.

Hasil pengujian hipotesis 1 menunjukan bahwa X1 ( Perceived Value ) mempengaruhi Y ( Niat Beli Kembali ) dengan koefisien sebesar 0,253 dengan tingkat signifikansi $0,008<0,05$ yang artinya variable Perceived Value cukup berpengaruh terhadap Niat Beli Kembali.

Hasil pengujian hipotesis 2 menunjukan bahwa X2 ( Perceived Ease of Use ) mempengaruhi Y ( Niat Beli Kembali ) dengan koefisien sebesar 0,275 dengan tingkat signifikansi $0,005<0,05$ nilai ini yang paling tertinggi di antara variable lain yang artinya variable Perceived Ease of Use sangat berpengaruh terhadap Niat Beli Kembali.

Hasil pengujian hipotesis 3 menunjukan bahwa X3 ( Perceived Usefulness ) mempengaruhi Y ( Niat Beli Kembali ) dengan koefisien sebesar 0,243 dengan tingkat signifikansi $0,044<0,05$ yang artinya variable Perceived Usefulness cukup berpengaruh terhadap Niat Beli Kembali. 


\section{KESIMPULAN}

Dari hasil analisis dan pembahasan dapat disimpulkan bahwa,

5.1 Hasil pengujian hipotesis 1 menunjukan bahwa X1 ( Perceived Value ) mempengaruhi $\mathrm{Y}$ ( niat beli kembali ) dengan koefisien sebesar 0,253 dengan tingkat signifikansi $0,008<0,05$ yang artinya variable perceived value cukup berpengaruh terhadap Niat Beli Kembali.

5.2 Hasil pengujian hipotesis 2 menunjukan bahwa X2 ( Perceived Ease of Use ) mempengaruhi Y ( Niat Beli Kembali) dengan koefisien sebesar 0,275 dengan tingkat signifikansi $0,005<0,05$ nilai ini yang paling tertinggi di antara variable lain yang artinya variable Perceived Ease of Use sangat berpengaruh terhadap Niat Beli Kembali.

5.3 Hasil pengujian hipotesis 3 menunjukan bahwa X3 ( Perceived Usefulness ) mempengaruhi Y ( Niat Beli Kembali ) dengan koefisien sebesar 0,205 dengan tingkat signifikansi $0,044<0,05$ yang artinya variable Perceived Usefulness cukup berpengaruh terhadap Niat Beli Kembali.

\section{REFERENSI}

Alter, Steven. 1992. Information systems : A Managemen Perspective. Benjamin Cummings, California.

Arief ,Wibowo. 2006. Kajian Tentang Perilaku Pengguna Sistem Informasi dengan Pendekatan Technology Acceptance Model (TAM).

Basu, Swastha .2005. Manajemen Penjualan Cetakan ke-duabelas. Yogyakarta: Liberty Yogyakarta

Durianto, Sugiarto dan Sitinjak.2001.Strategi Menaklukan Pasar Melalui Riset Ekuitas dan Perilaku Merek.Jakarta: PT Gramedia Pustaka Utama.

Davis.1989. Perceived usefulness, perceived ease of use, and user acceptance of information technology. MS Quarterly (online), Vol. 13 Iss. 3, pg. 318.

Davis.1989. Perceived Usefulness, Perceived Ease of Use, and User Acceptance of Information Technology. MIS Quarterly. Vol. 13 No. 5: pp319-339.

Davis, Bagozzi and Warshaw.1989. User acceptance of computer technology: A comparison of two theoretical models. Management Science (online), Vol.35 Iss. 8, pg. 982.

Igbaria, M., A. Chakrabarti. 1990. Computer anxiety and attitudes towards microcomputer use. Behaviour Inform. Tech. 9(3) 229-241.

Indriantoro, Nur dan Bambang Supomo.1999.Metodologi Penelitian Bisnis. Yogyakarta: BPFE.

Lee, Chai Har; Eze, Uchenna Cyril dan Ndubisi,Nelson Oly. 2011. Analyzing Key Determinants of Oneline RepurchaseIntentions. Asia Pacific of Marketing and Logistics Vojlume 23, Number 2.

Lui,Hk dan Jamieson, R-mb.kj2003, TRITAM $=$ A model for integrating Trust and Risk perceptions in business 40 consumer electronic commerce, 16th Bled E- Commerce Conference Transformation Bled, Slovenia, june : 349-364.

Kotler, Philip. 1995.Manajemen Pemasaran, Perencanaan dan Pengendalian, Edisi keenam.Jakarta : Erlangga.

Philip, Kotler, dan Armstrong, Keller 2009. Manajemen Pemasaran. Jilid : 2. Edisi : 13. Jakarta: Erlangga.

Saade dan Bahli, B .2005. The impact of cognitive absorption on perceived usefulness and perceived ease of use in on-line learning : an extension of the technology acceptance model, Information \& Management: 317-327.

Sugiyono.2004. Metode Penelitian Bisnis.Bandung :Alfabetha.

Tjiptono, Fandy .2004. Pemasaran Jasa .Malang : Bayumedia Publishing. 
Vankatesh, V. Morris et al.2003. User Acceptance of Information Technology: Toward a Unified View.MIS Quartely. Vol. 27 No. 3: Hal 425-478.

Wen, Chao, Prybutok, Victor.R dan Xu, Chenyan .2011.An Integrated Model for Customer Online Repurchase Intention. 2011. Journalof Computer Information Systems.

Yea Lin, C. Fang, K. dan Chung Tu, C.2010.Predicting Consumer Repurchase Intentions to Shop Online, Jurnal of Computers, Vol. 5, No.10, Douliou City,.Taiwan. 
JURNAL MANAJEMEN VOL 4 NO.2 DESEMBER 2014 